\title{
Investigating Bangladeshi university students' willingness to communicate (WTC) in English classes through a qualitative study
}

Md Rabiul Alam ( $\sim$ rabiulalam.um@gmail.com )

\section{Original article}

Keywords: EFL learning, oral communication, willingness to communicate (WTC), grammar-based teaching, classroom environment, tertiary level, Bangladesh

Posted Date: November 1st, 2021

DOI: https://doi.org/10.21203/rs.3.rs-1033882/v1

License: (c) (1) This work is licensed under a Creative Commons Attribution 4.0 International License.

Read Full License 


\section{Abstract}

In Bangladesh, learning English starts as a compulsory subject like other core subjects from the very early stage of a learner. However, after spending at least 12 years in learning English, learners' oral skill is not seen up to the mark while they enter into the university for their tertiary education. Sometimes, they are noticed to have their unwillingness to communicate with others. Hence, the current study aims to see the experiences of Bangladeshi university students' willingness to communicate (WTC) by employing a multiple case study method. 10 undergraduate students from a private university were interviewed. Apart from semi-structured interview, classroom observations were also carried out for data collection. The obtained data were analysed through the content analysis process. The findings show that students' earlier experiences of learning English have been positive; however, they see grammar-based English learning as an obstacle in their communication development. It also reveals that learners' WTC is greatly influenced by classroom environment that enhances or declines learners' interest to communicate with others. Based on the findings, the study suggests incorporating more drills in English classes by engaging learners with real-life based conversations, dialogues and so forth to enhance learners' WTC. Hence, learners' real voice would help the policymakers and language instructors to take the issue into consideration and way-out timely measures. As the study has considered fewer respondents, future studies are expected to shed light on more respondents including the voice of the teachers to have a deeper understanding of the issue.

\section{Introduction}

In the education policy of Bangladesh, teaching and learning English starts at the very beginning of children's schooling and learning English is a compulsory subject like other core subjects (Obaidul Hamid, 2010; Rahman \& Pandian, 2018). In every class, learners need to pass the English course to be promoted in the next class. Learners should study English at least 12 years before taking admission into university. However, it is very worrying that after studying several years in English-medium instruction at university level, they suffer from hesitation while they are asked to speak English before the audience (Fushino, 2011; Rahman et al., 2019).

Actually, the oral English proficiency of the Bangladeshi students is lower compared to the other Asian countries. But it is a good news that the govt. of Bangladesh has taken some policies from the elementary schools to develop the speaking and the listening ability of the students very aptly and minutely (Al Amin \& Greenwood, 2018; Rahman et al., 2019). No step will see the light of success until the learners have strong determination, motivation, and willingness to learn the language; and absence of these compels them to drop-out from their academic arena. Willingness to learn the language will obviously stimulate the learners to communicate in English. Otherwise, every single effort in this regard will be futile. However, studies are very rare to empirically investigate the learners' WTC in English classes in the context of Bangladesh. Hence, the current study aims to see the experiences of Bangladeshi university students' willingness to communicate (WTC) by employing a multiple case study method. Two research questions were used to achieve that objective: 
Question 1: What are the experiences of Bangladeshi university students in English oral communication classes?

Question 2: How do these previous experiences influence their willingness to communicate (WTC) in their university English classes?

In this regard, 10 undergraduate students from a private university have been selected and interviewed to collect the data. The collected data have been analysed through the process of content analysis to extract pivotal themes. The findings show that students' earlier experiences of learning English have been positive although they see grammar-based English learning as an obstacle in their communication development. It also reveals that EFL learners' WTC is greatly influenced by classroom environment which also affects their flow of interaction in English with their classmates. The study contributes to the literature by providing a practical experience of WTC that would help the policymakers and language instructors to take the issue into consideration and take measures accordingly.

The remainder of the study has been ordered in the following chronological order. Literature review has been placed in section 2 followed by a detailed description of the methodology in section 3 . Section 4 provides the findings and analysis of the study while section 4 elucidates the recommendation. Finally, conclusion has been provided in section 5 .

\section{Literature Review}

Every learning depends on the zeal and willingness of learners. Without having a definite willingness to learn or to communicate, no learner of second language can acquire language and hence can communicate properly. Realising the importance of willingness to communicate (WTC), a good number of qualitative studies (e.g., Basöz \& Erten, 2019; Peng, 2012; MacIntyre \& Legatto, 2011), quantitative studies (e.g., Maclntyre \& Doucette, 2010; Yashima, 2002) and mixed-method researches (Léger \& Storch, 2009) have been carried out. However, the practical learning experiences of the students reckoning their real voices about WTC problems should be given more focus. Hence, this literature review insinuates WTC with a focus to analysing the prevailing studies pertinent to EFL learning.

\subsection{Prevailing studies on WTC}

A good number of studies by the scholars across the world have been carried out depicting the relationship between WTC and English language learning. Basöz \& Erten (2019) have carried out a qualitative study where they interviewed 32 undergrad students in Turkey and found that factors like class size, vocabulary stock, teachers' behaviour, classroom environment, L2 anxiety, lack of actual pronunciation, shyness, peers' attitude, fear of making mistakes, etc. have a great influence on enhancing learners' WTC. Yashima (2002) conducted a study on Japanese learners' international attitude, where the researcher concentrates on WTC as well as the indicators which have impacts on learners' oral English discourse. For instance, taking a sample of 62 college studying students, the empirical study of Nakatani (2010) found that two principal strategies like maintaining discourse as well as negotiation of meaning 
are helping students to develop the communication ability. Besides, maintaining discourse is very essential for the learners in WTC with a view to participating actively in communication activity.

Another study conducted by Provenzano and Yue (2011) analysing a sample of 114 students reveals that speaking homework is helpful to enhance the opportunity for using English. The participants believe that extra practice is helpful for improving their knowledge of discourse that augments the level of their confidence and proficiency in English. The same result was found in a research conducted by Shawer (2010) in which he used qualitative research and reported that communicative approaches practiced by the teachers are very fruitful in increasing the language skill of the learners. In a mixed method study by Al-Murtadha (2019) showed that the use of visualization in the classroom by the language teachers can improve L2 learners' WTC in classes. In the context of Yemen, the researcher also suggested that teachers can implement various types of interesting activities to stimulate learners' WTC.

Besides, Fushino's (2011) study in the context of Japanese university students pointed out that learners' English practice had a great impact on communication. He also noticed that hands-on experience helps learners in developing their real English usage outside the classroom. However, negative result was found in case of students of high school by the study of Watanabe (2013) in which he showed that the learners did not improve their English ability after studying 3 years. Even though a native English speaker was provided them with ample amenities, they, however, could not enhance their proficiency in speaking English. The learners only enjoy the lessons which actually do not indicate that they are learning. In fact, basic English teaching has different goals like meaning-focused in primary school and more formfocused in junior high school.

\subsection{Factors Associated with WTC}

Researchers find varied factors that affect WTC. The principal indicators which influence WTC are classroom environment (Peng, 2019), learners' views (Trinder, 2013), learning motivation (Ma et al., 2019), metacognition of oral communication (Sato \& Dussuel Lam, 2021), universal attitude (Yashima, 2002), teacher immediacy attributes (Sheybani, 2019), and communicative assurance (Fushino, 2010). Besides, a group of scholars like Zhou (2012), Carreira (2011), and Zhao (2012) consider inspiration as an important factor for L2 learning. Other scholars (Zhong, 2013; Lockley \& Farrell, 2011; Knell \& Chi, 2012) think the observed competency as an important factor for target language learning that is associated with WTC. In fact, the above researchers dealt their studies with quantitative study with not having real learners' voices. The quantitative study conducted by Lee \& Hsieh (2019) in the context of Taiwanese EFL undergraduate students shows that learners with perseverance and higher level of confidence have greater WTC. They also show that learners of the current and digital age always feel more comfortable with digitally equipped learning setting rather than traditional classroom settings.

However, they find that EFL learners' L2 anxiety has a negative impact on learners' WTC and this view is also supported by the study of Dewaele (2019) that took place in the context of EFL learners of Spain. On the other hand, foreign language enjoyment and use of English by the L2 instructors motivate students to enhance L2 learners' WTC (Dewaele, 2019). Among many other factors, technology-based factors are 
seen to have positive impact on augmenting learners' WTC. In this regard, the study carried out by Tai \& Chen (2020) in the context of eighth-grade Taiwanese students shows that EFL learners' WTC in English classes is very positively associated with the use of Google Assistant software. In addition to the above, boosting learners' WTC makes them self-regulated learners where teachers' need to monitor them less. Making learners self-regulated, teachers' role by implementing various timely strategies plays a vivid role (Segaran \& Hasim, 2021). It is noted that learners' who are guided by strategic planning are seen more efficient in their oral production than those guided by no plan (Bakhtiary et al., 2021). Hence, teachers' positive and direct involvement is also a dominating factor to enhance learners' WTC. Synthesising all the findings of the past studies, a fruitful argument is required for the learners' real voices for learning English and the way of developing their English speaking.

\subsection{Grammar-based Learning}

The amalgamation of grammar-based and communicative language teaching approaches are believed as the top methods in acquiring any language. Yet, grammar-based approach is regarded as one of the worst indicators for the students in the education system (Basöz \& Erten 2019; Falout, Elwood, \& Hood, 2009). Studies show that most of the high school students in the context of Japan do not like English and are less-focused to grammar learning as they think that grammar creates obstruction in their language learning (Kikuchi and Browne, 2009). Another study shows that learners feel more comfortable to learn the language in informal setting where grammar is taught inductively (Hasan et al., 2019).

\subsection{Impact of Early Learning of English}

It is generally believed that practice is essential to learn a language quickly. Learning $L 2$ at the very early stage assists learners to be communicatively competent and learners $L 2$ competence is very positively associated with their WTC (Zhou, Xi, \& Lochtman, 2020). However, there is a debate about the exact time of starting practice of a language. Besides, the researchers are in a debate regarding the benefit on proficiency in early starting whether it would be in primary school or in junior high school. But early start is regarded as the most fruitful time for achieving the overall abilities in a language (Huang, 2011).

On the contrary, early starting has a little impact on proficiency in a language (Larson-Hall, 2008). Actually, the young students who are provided more amenities for learning a target language, they develop their oral skill very smoothly in communication with quality and quantity (Huang, 2011). The early start seems to be an easy issue but there are two groups of researchers who have shown their arguments with empirical data in favour of their studies

For instance, early starting of learning English in the govt. primary schools is not without antagonism. Actually, the education system of any country should give more concentration on its own resources and context related contents that will help students improve their communication skills. It does not mean that English is ignored but it can be taught at next levels like junior high school as well as college (Torikai, 2005). Besides, early start of learning a language helps the learners only in phonemic ability not morphological ability (Larson-Hall, 2008). Actually, it means early start of learning English only develops 
the pronunciation of some words in English not the formation of word to produce a language. Hence, the researchers are in a confusion regarding the advantages of early starting age as the input is very little like a few hours, a week, a month etc.

\section{Methodology Of The Study}

A qualitative case study has been deployed in this current study. Through a qualitative case study, the experiences of Bangladeshi university students enrolled in intensive English classes and the effect of their past experiences on the WTC were examined and clarified. It took around 1 month to obtain the data for this study. In this multiple case study, each student was a participant. All students in the selected university were chosen from a single class.

\subsection{Population}

A private university located in Dhaka, the capital of Bangladesh with three basic thoughts was taken as the sample to get the fruitful result of the study. Firstly, the university has a lecturer to teach learners English who did his/her degrees from English speaking countries. Secondly, the university was very close to the researcher's house and it helps to conduct classroom observation as well as take interviews. Lastly, justifying a learner's WTC, low motivation and low English ability were expected on account of the nature of the research.

\subsection{Participants}

A non-random sampling method was used for this study to observe the speaking ability of the students in English and there were 10 classes in number of which one was chosen and for interviews, 10 students were taken out of total 41 learners in the classroom. At first, the selected learners were 15 in number and they were primarily chosen considering their getting marks on WTCQ. But finally, 10 students were kept as they were revealed enthusiastic for completing the study and they also got better marks than the primary ones. Among 10 participants, 6 participants were boys and 4 girls.

\subsection{Research instruments}

This study has mainly used WTCQ as research instruments to collect the data. The research instruments used at this single site were the initial WTCQ. Two sets of questions have been formed and asked the students. First set was mainly about their demographic information as well as known situations to describe so that their level of English can easily be understood. Second set was also about the topics that are somewhat unfamiliar with the students that they needed to think to answer. To have an in-depth understanding of the leaners' WTC, six in-class observations of 1 hour each were conducted. During the observation session, the researchers used observation protocol and took notes on important issues and happenings that need to analyse with more focus. Then, two semi-structured interviews were conducted in which the interview duration for each participant was 60 minutes. There were 10 students in the class who compromised 10 units analysed over a period of one month. There were also 1-hour follow-up 
interviews after the 1-hour direct classroom observations, where detailed questions regarding oral communication were asked in the classroom.

Handwritten notes were also available from both interviews and classroom remarks. These notes were intended to capture the feelings and emotional mood of the classroom which were difficult to obtain only through audio recorders. However, students used and checked audio transcripts for precision after the interview. As a method of data collection, the emotional environment is important to keep open discussions between the researcher and the students. In order to ensure accuracy later on, all data were archived.

The initial WTCQ helped the researchers to understand the willingness of the university students to speak in English in their classes. This was critical to decide what Bangladeshi university students are thinking about their WTC and what they actually do in the classes to enhance their speaking ability (Navarro and Thornton, 2011). One of the original authors in different age groups and communities tested the reliability of the initial WTCQ and proved its reliability (McCroskey, 1992). The scale is 20 items on average, eight items being fillers and 12 items being marked in the scale. This enables the current WTC students to be thoroughly evaluated. The reliability of the WTC scale was measured in a model estimate of 0.92 in the United States as well as in other cultures (McCroskey, 1992). Therefore, it was possible to depend on the scale in this case study to predict the students' WTC accurately. The scale of the request was interpreted by a Bangladeshi university lecturer to truly comprehend what was being asked. Classroom observation were done for six classes to see the real scenario of the students whether they really interact with their classmates or not. The way of entering the classroom was to take six lessons each for one-hour that focus on building oral communication ability.

\subsection{Process of Data Collection and Analysis}

Prior to start the study, a primary survey was carried out to achieve a targeted sample. Two individual interviews were arranged with each participant following the selection and signing of the consent forms. The first interview had benn conducted in the first week before all classroom observations were made. The second interview was completed after all the six observations in the classroom with the intention of providing more information about student experience. For both the interviews, a total of 30 questions were structured.

At first no preconceived codes were available. Codes were produced and collected by transmitting data and by deductively dividing the qualitative data into less important sections. These sections were subdivided by reading and codifying the data over and over again. Qualitative software has helped to evaluate a large quantity of data through cross-references and the quest for correlations between data. Keywords to assist in coding different knowledge segments were established.

Data is examined into an inductive process of reasoning. The WTC level was tested in English without any previous expectations. In a non-judgmental exploratory environment, the learners were given the opportunity to express their experiences in order to discuss about research questions in this study. Data 
were also analysed by clustering and the grouping into significance of important statements. Clusters and groups were then used to support Bangladeshi university students with the WTC to understand their experiences.

\section{Results And Analysis}

According to the findings of the study, the learners believe that the contemporary oral English courses of the university and grammar-intensive instruction are not appropriate for learning English but actual communication is necessary for them to develop English proficiency skill. The similar outcome is found from the review of literature in which the researchers stated that merely $6 \%$ students of their research reveal that previous English-language teaching are helpful for them in developing their oral proficiency in communication (Kikuchi \& Browne, 2009). Before this research, lots of things were vague to the researchers regarding the communicative use of oral English for the learners of EFL classroom. This section deals with an assessment of the outcomes and their relation with willingness to communication as well as two interrogations of the research.

It is noted from the study that the general skill of the university students of Bangladesh was positive in learning English. Though grammar-based teaching was not preferable to them, they acknowledged its importance for learning English. The statement had been again voiced with longing for acquiring English with a view to enhancing the current proficiency in English. The result of this research also stated that the learners did not get enough chances for using English with other learners. Among the participated students, $69 \%$ didn't have any faith on their previous English learning experience and believed that their learning was meaningless (Mack, 2012). Besides, they also felt embarrassment with other learners because of having no practice of speaking in English. Semi structured interviews were used to know the prior experiences of the students. The main point of the study was that the policymakers should come forward to take steps regarding the current student voices. According to Mack (2012), only grammarbased pedagogy is not appropriate for the learners to deal with oral communication in future. When learners think of whether they are using grammatically correct sentences or not, this creates hindrances in their spontaneous conversation (Graham, Pan, \& Eslami, 2021; Nguyen \& Phu, 2020; Amini, 2018; Zeghdoud, Al-Haq, \& Al-Jamal, 2019).

Moreover, environment has a great effect on WTC and so, the learners could not communicate with other or in the classroom effectively. According to Peng $(2012,2019)$, congenial classroom environment is required for successful teaching and learning. However, the role of environment was not mentioned in case of WTC effectively. The findings of the research stated a number of probable causes in spite of having congenial atmosphere in the classroom.

Firstly, most of the students feel awkward because they do not know other students' names exactly and the way to start their dialogs with their mother tongue than a target language. In the study, it is found that a few students knew each other exactly. However, the students started speaking exercises with the help of the instructor when he began conversation with them. On the contrary, as soon as the instructor stopped 
conversation with them, it was seen that they also stopped practicing to learn their second language English. Secondly, participated learners in the research stated that such kind of communication was not known to them before. Lack of prior experience was also found in the classroom observations continually. According to Kikuchi \& Browne (2009), foreign language teachers believe that absence of prior experience is a foremost indicator for interaction in the classroom. The learners again stated that they did not feel easiness regarding communication on account of their poorest English capability.

Thirdly, a good number of the learners were very callous in active participation that influences on WTC. Peng $(2012,2019)$ stated that classroom environment has a great effect on students' participation in learning and their WTC as well. The participated students in this study showed a very negative reply regarding classroom environment. They stated whenever any conversation would start, someone would try to sleep or not pay any attention actively. These negative activities prove the way of the feelings of the students when they would practice second language. Finally, it was stated that prior experience in speaking English would surely develop the learners' existing WTC. Participants stated in the study that they began practicing English at the very 1 st class of primary school. Actually, merely 5 learners began to learn English properly before six-grade. While the participants were questioned regarding previous experiences of English learning, $68 \%$ students gave adverse reply like difficulties in English, not getting fun, or feeling uncomfortable in practicing English.

When the participants were asked in the second interview regarding the effect of early starting in speaking English on current WTC, they replied that it would improve their pronunciation with making learning fun. In a word, it would develop their confidence for learning their second language though one learner replied negatively. In fact, early starting must develop the existing WTC. According to GoorhuisBrouwer and De Bot (2010), an early learning English has a great advantage that enables learners to learn the target language properly. Moreover, according to Torikai (2005), early start learning of L2 has no negative effect on L1 proficiency and it is the argument that is recommended in elementary schools. Lastly, the five themes are described below using inductive codes that have a relation with the two questions of the study. Specially, the 1st study question deals with the learners' previous knowledge in learning English and the 2nd one is the role of preceding classes on the existing WTC.

\subsection{Positive Effect of Previous Experience}

The first theme of the study was that the students' prior experience was beneficial, but their approaches of learning could have been developed. Actually, it was not a desirable result. Specially, the students informed that the grammar based learning was a barrier in developing oral proficiency as well as the learners' WTC.

In the study, total 6 learners stated that their previous skill in learning English was not bitter for their lives though only four students openly gave negative reply like negligence of oral English or scarcity of curiosity in learning English owing to preceding education. Among the learners only three learners had given negative reply regarding the advantages of former knowledge of English learning. They stated like- 
"it was not good quality", "the mixture of good and bad". Another eight students (80\%) gave positive reply with the words like- "very good", "it helped us a lot", as well as "great motivation". Some of them replied like- "great experience so far, but waiting for the final outcome." Another participant informed that he acquired an excellent knowledge and desired for early starting. The learner who got the utmost WTCQ mark, stated that speaking with natural English orators is "a decent thing".

When the students were questioned regarding their previous skills of learning, one learner (female) informed that her experience was "very good" as she began to learn English at the very outset of schooling though she revealed that oral English learning was not proper for his present class. Another male student also replied the same answer if he had learned English at an early stage of education, his current path of learning would not have been difficult. Lastly, participated students stated that their previous knowledge of learning English would be developed if they could include more fun with their prior lessons. According to one learner, the methods of learning were compulsory to him. The rest learners informed about their eagerness to learn unknown thing at varsity level getting out from previous grammar-based teaching. Yet, other learners stated if they were taught English with interest at elementary level, they would be more curious to learn English now.

\subsection{Grammar-based learning has negative impact on WTC}

From the interviews and classroom observations, the second theme has denoted that there were a large number of students reporting that grammar styles in Bangladesh were no reason to learn or communicate in English. The findings indicate that, apart from the perception that grammar is not beneficial to their general English knowledge, Bangladeshi university students also feel that grammarbased prior learning has stopped them from compensating for oral communication. Eight students, or $80 \%$, indicated that they had learned nothing after at least 12 years of English learning, and this made them reluctant to learn and practice English in their current position. When the interview specifically asked students what they could do to enhance their ability to speak English, no student stated that it would help to study further grammar.

About 50\% respondents said that speaking English with native English speakers would be a good way to develop their skills rather than learning grammar. Grammar-based learning makes them worried whether they are speaking grammatically correct English or not that hinders their spontaneous conversation. One of the students said, "As I am worried about using correct grammar, I stop speaking with others in English." In his second interview, this same student said, "If I can't speak English, it's simple I can't write English." Hence, learning English in a natural setting is much better that learning through memorising grammatical rules or structures.

The study also shows that students do not like learning grammar too intensively and do not think they will study all of their English lessons. Instead, students claimed that their lives would receive better communication. The students also stated that they should be taught those parts of English intensively that are very much useful in their daily communication. They should be taught considering events happening in their real life without focusing more on grammatical structures. By this way, they can learn

Page 10/18 
good English that will be stable in their memory for long time as said by one participant, "learning naturally would remain stable for long".

\subsection{Environment has a significantly positive impact on WTC}

While analysing data, main concentration had been given on previous English skills of the learners to evaluate whether the skills had any effect on the learners' present WTC. It was found in the result that the present skills of rote style learning as well as grammar-based teaching were not helpful for the learners in regard to communication in the target language and it did not make any congenial environment for spontaneous communication in speaking drill. Each learner reported that settings had a great effect on WTC. For instance, one student said, "I feel comfortable to talk with my friends not others." Some participants noted that while the classroom remains 'calm', they stop practicing. 90\% of the participants reported that the physical environment, teachers' behaviour, and other learners' outlook as well are important for enhancing the speaking ability of the students. Actually, it was proved that the environment, learners' ability and personality have a significantly positive influence on their WTC. A good number of students reported that they did not know English because of their poor ability in English. Whenever personality was mentioned, the students replied that they could not speak in English on account of their shyness as well as embarrassment etc.

\subsection{WTC is not higher with their classmates}

The fourth theme of the study shows that the students don't want to speak English with other students that denotes lower WTC with other students or their classmates. Many participants state that their WTC seems to be higher with their course instructor while they see their WTC is lower with their class friends. Several students said that "talking with our friends in English is unnecessary." It was found true during classroom observation that students were seen uncomfortable to speak in English with other students in classroom. They have proved this by using their cell phones rather than communicating with other students or by making their book and by not doing target language with their assigned partners. In group activities, students have been noticed many times when they just sit down in the group and apparently ignore the others.

While they were asked to know the reason behind this, many of them replied, "everyone remains busy with their mobile phone, none starts speaking in English". They also state that many of them think that they know better than others which makes them reluctant to speak in English. But this appears to be different while it is with their course instructor whom they are compelled to speak. In fact, they sometimes felt forced to do something that they would not want to do by attempting to talk to other students in English.

The interview results showed that, although students have spent many years studying English, they do not know how to speak if they are given the chance. One male student said that he was trying to use English, but he was not sure if the other person understood his English. He also said that he would not try anymore with this feeling. Many participants said that they were prevented from trying due to the lack of actual pronunciation of English words. As their pronunciation is not up to the mark, they feel shy when they are in a situation to speak in English. They cannot speak English because they feel shy and 
embarrassed. $70 \%$ of the participants noted that they speak in English in the classroom at the very beginning, but they stop practicing it while they see most of the students speak in their native tongue Bengali. This creates an awkward situation and compels them to leave talking in English.

\subsection{Practicing at the early stage improves WTC in the current stage}

The most noticeable thing was the final theme of this study. Every learner reported if they had prior experience of proper learning English at an early age, they would not have felt the lack of WTC now. These data had been used in answering the second research question regarding the role of prior experience on their current WTC. It was found in the study that all the participants except one revealed if they had got opportunity to practice English properly at the 1st grade of primary school, their present language acquisition would have been developed. However, they all mentioned if they had got chance for early study in learning English, their shyness would have been blotted out and EFL would be more fun to them.

Moreover, students' remarks regarding early starting like "gateway to learn English easily" and then their "stickiness with them" were noted. One participant posed a great comment about learning English early. He said that early learning of English would encourage further development of learning with fun. He believed if early interest was accomplished, learners would do well in university level. Special emphasis should be given on the remark of a participant in which he rejected previous practice with oral communication and stated his callousness of stickiness in language. He believed, "you must practice English, otherwise you will forget it". Another student made a very nice comment by saying, "we dream to be a good speaker, but we are reluctant to practice it".

Hence, based on the students' remarks, if they got the proper environment of learning English at the very 1st grade of primary school, their present English knowledge as well as WTC would have been more developed. For example, when the students were given compulsory grammar-based teaching at their primary school without teaching them with fun, they would neglect the English learning as well as loss their eagerness to learn English. Moreover, the particular voice of students regarding early learning English with early age has been found in this study project. It was not mentioned that early starting of learning the English language must develop their English skill, but it would help them enhance confidence and motivation with a view to learning English, and so their learning process would be more fun and enjoyable to them.

\section{Recommendations}

The first suggestion is to make sure that the potential researchers do not extend the findings of this study specifically to all Bangladeshi students. Instead, prospective researchers should take these findings as a guide to conduct more studies in this field in the form of either quantitative, qualitative or mixed method studies. This study has picked up the real voices of students by using interviews and classroom observations to determine whether existing policies are what students believe to be the best for them. In 
two interviews with the results of this research, students thought that further communication would be more relevant to their needs. The results of the study therefore introduce to current WTC literature by exposing current pedagogical practices of Bangladeshi university students and how EFL learners see their verbal communication instruction.

Secondly, the findings of this study recommend to use more drills in university English classes to enhance learners' communication skill. Hence, modified and time-tested teaching techniques should be implemented as a number of participants claimed pedagogical issue as a key problem to their current lack of the WTC. The essential skills of an oral communication in a foreign language could also lack potential students without a stronger and more comprehensive knowledge of the current mandatory pedagogy. The key issue is that students must focus themselves on their comprehension of oral communication and less on grammar as an apathy for the English language. Therefore, more and more qualitative, quantitative, and mixed method studies should be carried out to have a fruitful understanding of learners' WTC in English classes that will widen the policy implications in this regard.

The final suggestion is that young Bangladeshi students will be introduced to oral English interactions as soon as possible. Students in this study said that their ability to speak earlier would have significantly improved. Further practice with other students, particularly during meaningful oral dialogue, will assist Bangladeshi students in elementary school English classes that will enhance their WTC in the later stage of education. In addition to helping to limit cultural misunderstandings at an early level of exposure to oral English, international instructors claim that because of lack of motivation or necessity, students are unable to communicate. However, learning English properly at the early stage will be very much helpful in their later academic life to learn the language enthusiastically which will enhance their WTC too (Rivers, 2012).

\section{Conclusion}

Prevailing studies have found that EFL learners' WTC are highly influenced by their past experiences in oral communication in English. Though many studies have been conducted in this regard, actual student interviews and perspectives were one of the key missing elements in the prior studies. Hence, this current study has filled this gap and contributed to the literature by providing real voice of the Bangladeshi university students about WTC in English classes. The five concepts described in this study only begin to understand how past experiences influenced current WTCs of students at universities. The students said overall previous experience was positive but there are still areas in which improvements need to be made. The five themes have also been interwoven, as this improvement would affect other fields if it was improved. In particular, removing established grammar-based learning and introducing a more communicative approach early in oral English training will increase the likelihood of students engaging not only in the target English language, but also improve and encourage WTC's overall environment in the classroom. 
The four suggestions based on the findings of this study were also discussed with a view to enhancing the learning environment of prospective students in order to improve the WTC. All students in Bangladesh cannot be affected by the results of this study. However, in university environments there are many ways to encourage the increase in the WTC. Change in policy is possibly the first move that university administrators may want to take in order to encourage active involvement in classrooms.

Changing policies representing a longer classroom in communication would take time and resources but also cost a great deal if we keep following current grammar-intensive pedagogy that does not meet the needs of students. Through more case studies throughout Bangladesh, students' voices are heard and the factors preventing WTC are understood. It remains to be discovered that this further research would also suggest that students want an earlier initiation of oral English communication, however it can be assumed that more empirical evidence is available, better university administrators are to make decisions.

In conclusion, student interviews and observations in the classroom were essential to understand the current WTC of Bangladeshi university students. Yet further research is required to unveil students' past encounters with WTC and oral English classes in order to make meaningful improvements. In this study, students expressed their concerns about two interviews where they were allowed to express their views. The research can now be used by university policymakers to enhance their understanding of previous university student experiences. In addition, more research into the WTC of Bangladeshi students would potentially improve students' speaking skills in Bangladesh.

\section{Declarations}

\section{Acknowledgements}

The early version of this manuscript was presented at the $2^{\text {nd }}$ Malaysian Association of Applied Linguistics International Conference 2021. Authors are grateful to those participants who made insightful comments and suggestions for the improvement of this manuscript.

\section{Funding}

This study has not been supported by any funding agency or institution.

\section{Availability of Data}

All the data used in this study belong to the corresponding author and will be shared upon reasonable request.

\section{Authors' Contributions}

All the authors have equally made significant contributions in conceptualizing, drafting, interview questions preparing, editing, and proofreading of the manuscript. However, data collection have been 
solely carried out by Md Rabiul Alam and Rashed Khan Milon.

\section{About the Authors}

Md Rabiul Alam and Diana Ansarey are PhD candidates in TESL and English respectively at the University of Malaya, Malaysia. Besides, they are the faculties at two prominent private universities in Bangladesh. Md Rashed Khan Milon is the Head of English Department, Port City International University, Bangladesh and a PhD candidate at Jagannath University in Bangladesh. Md Masud Rana is the Coordinator at the English Language Institute, Jazan University, Saudi Arabia. Huzaina Abdul Halim is a Senior Lecturer in TESL at the Faculty of Education, University of Malaya, Malaysia. She did her PhD from the Imperial College, UK. Rabeya Khatun Mitu is a lecturer, Department of English, Asian University of Bangladesh.

\section{Conflict of Interest}

The authors declare no conflict of interest regarding this study.

\section{References}

1. Al Amin, M., \& Greenwood, J. (2018). The UN Sustainable Development Goals and Teacher Development for Effective English Teaching in Bangladesh: A Gap That Needs Bridging. Journal of Teacher Education for Sustainability, 20(2), 118-138

2. Al-Murtadha, M. (2019). Enhancing EFL learners' willingness to communicate with visualization and goal-setting activities. TESOL Quarterly, 53(1), 133-157

3. Amini, D. (2018). The Effect of Feedback Timing on the Acquisition of Simple Past Form: Relevance of Willingness to Communicate (Doctoral dissertation, Azarbaijan Shahid Madani University)

4. Bakhtiary, M. R., Rezvani, E., \& Namaziandost, E. (2021). Effects of strategic and unpressured withintask planning on iranian intermediate EFL learners' oral production. Journal of Nusantara Studies (JONUS), 6(2), 97-115

5. Basöz, T., \& Erten, I. H. (2019). A Qualitative Inquiry into the Factors Influencing EFL Learners' In-Class Willingness to Communicate in English. Novitas-ROYAL (Research on Youth and Language), 13(1), $1-18$

6. Carreira, J. M. (2011). Relationship between motivation for learn-ing EFL and intrinsic motivation for learning in general among Japanese elementary school students. System, 39, 90-102

7. Dewaele, J. M. (2019). The effect of classroom emotions, attitudes toward English, and teacher behavior on willingness to communicate among English foreign language learners. Journal of Language and Social Psychology, 38(4), 523-535

8. Falout, J., Elwood, J., \& Hood, M. (2009). Demotivation: Affective states and learning outcomes. System, 37, 403-417 
9. Fushino, K. (2010). Causal relationships between communication confidence, beliefs, about group work, and willingness to com- municate in foreign language group work. TESOL Quarterly, 44, 700744

10. Fushino, K. (2011). Students' reactions to a group project in a university English-as-a-foreignlanguage class for cultural understanding. Intercultural Education, 22(4), 301-316

11. Goorhuis-Brouwer, S., \& De Bot, K. (2010). Impact of early English language teaching on L1 and L2 development in children in Dutch schools. International Journal of Bilingualism, 14, 289-302

12. Graham, K. M., Pan, W. Y., \& Eslami, Z. R. (2021). A critique of Taiwan's bilingual education policy through a ROAD-MAPPING of teacher experiences. Current Issues in Language Planning,1-19

13. Hasan, M. R., Rashid, A., Hasan, R., Nuby, M., \& Alam, M. R., M., \&. (2019). Learning English Informally Through Educational Facebook Pages. International Journal of Innovation, Creativity and Change, 7(7), 277-290

14. Huang, K. (2011). Motivating lessons: A classroom-oriented investigation of the effects of contentbased instruction on EFL young learners' motivated behaviours and classroom verbal interaction. System, 39, 186-201

15. Kikuchi, K., \& Browne, C. (2009). English educational policy for high schools in Japan: Ideals vs. reality. RELC Journal, 40, 172-191

16. Knell, E., \& Chi, Y. (2012). The roles of motivation, affective attitudes, and willingness to communicate among Chinese students in early English immersion programs. International Education, 41(2), 66-87

17. Larson-Hall, J. (2008). Weighing the benefits of studying a foreign language at a younger starting age in a minimal input situation. Second Language Research, 24, 35-63

18. Lee, J. S., \& Hsieh, J. C. (2019). Affective variables and willingness to communicate of EFL learners in in-class, out-of-class, and digital contexts. System, 82, 63-73

19. Léger, D., \& Storch, N. (2009). Learners' perceptions and attitudes: Implications for willingness to communicate in an L2 class- room. System, 37, 269-285

20. Lockley, T., \& Farrell, S. (2011). Is grammar anxiety hin- dering English speaking in Japanese students? JALT Journal, 33, 175-190

21. Ma, X., Wannaruk, A., \& Lei, Z. (2019). Exploring the Relationship between Learning Motivation and L2 WTC in an EFL Classroom among Thai EFL Learners. English Language Teaching, 12(7), 33-45

22. Maclntyre, P. D., \& Doucette, J. (2010). Willingness to communicate and action control. System, 38, 161-171

23. Maclntyre, P. D., \& Legatto, J. J. (2011). A dynamic system approach to willingness to communicate: Developing an idio- dynamic method to capture rapidly changing affect. Applied Linguistics, 32, 149-171

24. Mack, L. (2012). Does every student have a voice? Critical action research on equitable classroom participation practices. Language Teaching Research, 16, 417-434 
25. McCroskey, J. C. (1992). Reliability and validity of the willingness to communicate scale. Communication Quarterly, 40(1), 16-25

26. Nakatani, Y. (2010). Identifying strategies that facilitate EFL learn- ers' oral communication: A classroom study using multiple data collection procedures. The Modern Language Journal, 94, 116136

27. Navarro, D., \& Thornton, K. (2011). Investigating the relationship between belief and action in selfdirected language learning. System, 39, 290-301

28. Nguyen, N. Q., \& Phu, H. B. (2020). The Dogme Approach: A Radical Perspective in Second Language Teaching in the Post-Methods Era.Journal of Language and Education, $6(3$ (23))

29. Obaidul Hamid, M. (2010). Globalisation, English for everyone and English teacher capacity: Language policy discourses and realities in Bangladesh. Current Issues in Language Planning, 11(4), 289-310

30. Peng, J. E. (2012). Towards an ecological understanding of willingness to communicate in EFL classrooms in China. System, 40, 203-213

31. Peng, J. E. (2019). The roles of multimodal pedagogic effects and classroom environment in willingness to communicate in English. System, 82, 161-173

32. Provenzano, C., \& Yue, S. (2011). Take it outside!-Speaking homework for English communication classes. Intercultural Communication Studies, XX, 220-238

33. Rahman, M. M., \& Pandian, A. (2018). A critical investigation of English language teaching in Bangladesh: Unfulfilled expectations after two decades of communicative language teaching. English Today, 34(3), 43-49

34. Rahman, M. M., Islam, M. S., Karim, A., Chowdhury, T. A., Rahman, M. M., Seraj, P. M. I., \& Singh, M. K. M. (2019). English language teaching in Bangladesh today: Issues, outcomes and implications. Language Testing in Asia, 9(1), 1-14

35. Rivers, D. J. (2012). Modelling the perceived value of compulsory English language education in undergraduate non-language majors of Japanese nationality. Journal of Multilingual \& Multicultural Development, 33, 251-267

36. Sato, M., \& Dussuel Lam, C. (2021). Metacognitive instruction with young learners: A case of willingness to communicate, L2 use, and metacognition of oral communication.Language Teaching Research,13621688211004639

37. Segaran, M. K., \& Hasim, Z. (2021). TEACHER MANAGEMENT OF SELF-REGULATED LEARNING THROUGH ePORTFOLIO. Journal of Nusantara Studies (JONUS), 6(1), 373-393

38. Shawer, S. (2010). Communicative-based curriculum innovations between theory and practice: Implications for EFL curriculum development and student cognitive and affective change. The Curriculum Journal, 21, 333-359

39. Sheybani, M. (2019). The relationship between EFL Learners' Willingness to Communicate (WTC) and their teacher immediacy attributes: A structural equation modelling. Cogent Psychology, 6(1), 1607051

Page 17/18 
40. Tai, T. Y., \& Chen, H. H. J. (2020). The impact of Google Assistant on adolescent EFL learners' willingness to communicate. Interactive Learning Environments,1-18

41. Torikai, K. (2005). The challenge of language and communication in twenty-first century Japan. Japanese Studies, 25, 249-256

42. Trinder, R. (2013). Business students' beliefs about language learn- ing in a university context. English for Specific Purposes, 32, 1-11

43. Watanabe, M. (2013). Willingness to communicate and Japanese high school English learners. JALT Journal, 35, 153-172

44. Yashima, T. (2002). Willingness to communicate in a second lan- guage: The Japanese EFL context. Modern Language Journal, 86, 54-66

45. Zeghdoud, M., Al-Haq, F. A. A., \& Al-Jamal, D. (2019). Communicative English Language Teaching Principles in Action: Moving from Theory to Examples. Jordan Journal of Modern Languages and Literatures Vol, 11(2), 225-246

46. Zhao, L. (2012). Investigation into motivation types and influences on motivation: The case of Chinese non-English majors. English Language Teaching, 5(3), 100-122

47. Zhong, Q. (2013). Understanding Chinese learners' willingness to communicate in a New Zealand ESL classroom: A multiple case study drawing on the theory of planned behavior. System, 41, 740751

48. Zhou, H. (2012). Enhancing non-English majors' EFL motivation through cooperative learning. Procedia Environmental Sciences, 12(Pt. B), 1317-1323

49. Zhou, L., Xi, Y., \& Lochtman, K. (2020). The relationship between second language competence and willingness to communicate: the moderating effect of foreign language anxiety. Journal of Multilingual and Multicultural Development,1-15 